\title{
Motyw 'okna' i’ lustra' u Zinaidy Gippius i Mariny Cwietajewej
}

\author{
Wojciech Gorczyca (Polsko)
}

\begin{abstract}
Abstrakt
Wiersze dwóch poetek o 'oknie' i 'lustrze' autor analizuje w kontekście założeń modernizmu i postmodernizmu. Z. Gippius jako reprezentantkę modernizmu wysokiego cechuje wzniosłość w wersji melancholijnej. Na tej bazie poetka przywraca wartość sprzeczności doznań: bólu, niemożności, nadziei. Interesuje ją transcendentalne odbicie w lustrze. Implikuje to skojarzenia z mitem Narcyza, a także symboliką „bramy”. Zmiany w sieci radialnej kategorii ‘okno' i ‘lustro’ u M. Cwietajewej odnieść należy do faktu, że nadaje ona „tej samej rzeczy” każdorazowo inny sens. W ten sposób rama okienna (jej cień) odbita na ścianie strychu symbolizuje krzyż, a ten świat. Kreuje taki stan rzeczy wektor skierowany ku dołowi oraz uznanie za istotną „część”, tj. 'ramę' okienną. Cwietajewa wprowadza 'zmianę', rozbijając lustro i eliminując z niego 'spojrzenie' (tj. stary punkt widzenia). W ten sposób rodzi się nowy horyzont zdarzeń.
\end{abstract}

\section{Słowa kluczowe}

modernizm; wektor skierowany ku górze, postmodernizm; wektor skierowany ku dołowi; wzniosłość; melancholijność; 'zmiana'; sens do odkrycia

\section{Abstract \\ The Motifs of Window and Mirror in Zinaida Gippius's and Marina Tsvetaeva's Works}

The author analyzes two poems of 'window' and 'mirror' of two poets in the context of tenets of modernism and postmodernism. Z. Gippius as a representative of the high modernism is distinguished by sublimeness in a melancholic version. On this basis, the poet restores the value of the contradiction of sensations: the pain, impossibility, hope. She is interested in a trascendental mirror reflection. This implies a connotation with the myth of Narcissus, as well as the symbolism of the 'gate' through which lyrical I cannot pass. The changes in radial network of the categories of 'window' and 'mirror' in M. Tsvetaeva's poetry should be referred to the fact that every time 'the same thing' is given a different meaning. This way a window frame (its shadow) reflected on the attic wall symbolizes a cross and, in effect - the world. This is created by a vector directed down and the fact that the 'part' - a window 'frame' is regarded as important. Tsvetaeva confirms the 'power' by breaking the mirror and eliminating a 'look' from it (an old point of view).

\section{Key words}

modernism; vector directed up; postmodernism; vector directed down; sublimeness, melancholy; sense is a task to be revealed 
Modernizm zrodził się w dobie Renesansu, a w Oświeceniu i Romantyzmie adaptował na swoje potrzeby hasło „wolność - równość - braterstwo”. Funkcjonował na przełomie XIX i XX wieku z jednej strony jako kierunek odrzucający teorie wolnościowo-rewolucyjne, z drugiej (np. w Rosji), je uwzględniał. Potwierdza to twórczość takich poetów, jak Walery Briusow, Wiaczesław Iwanow, Aleksander Błok. ${ }^{1}$ Podkreślmy, iż socjalizmy modernistyczne: komunizm, faszyzm, nazizm są klasycznie platońskie, bowiem są monopartyjne. Ich metodą działania jest rewolucyjność. ${ }^{2}$

Dwie znakomite poetki rosyjskie, Zinaida Gippius (1869-1945) i Marina Cwietajewa (1892-1941), tworzyły w okresie, w którym zderzały się dwie tendencje modernizmu, „wysoki” i ruchy awangardowe. Kiedy koledzy po piórze przechodzili na stronę rewolucji, Gippius w wierszu Żótte okno (Желтое окно, 1918) była wierna swemu „pejzażowi wewnętrznemu” z Bogiem w roli głównej, mimo że podejmowała wtedy i wcześniej decyzje „światopoglądowe" trudne i niebezpieczne. W 1905 roku opowiedziała się przeciwko samodzierżawiu, w 1906 roku związała się z eserami -- po październiku 1917 roku odrzuciła dzieło Lenina.

Modernizm uznawał sztukę za wartość autentyczną i autonomiczną, eksponował kult nowości i oryginalności oraz akcentował opozycję sztuki elitarnej, wysokiej wobec sztuki popularnej. Modernizm próbował używać języka estetycznie ukształtowanego, wyrafinowanego w swojej konstrukcji i charakterze. ${ }^{3}$ W latach osiemdziesiątych XIX wieku zaczynał sobie torować drogę symbolizm, oceniany niekiedy przez jego propagatorów jako „dekadentyzm”. Symbolizm charakteryzowała dążność do przedstawiania świata odmiennego w porównaniu z realną rzeczywistością. Symbol służył do oddania najgłębszych doznań i nastrojów. ${ }^{4}$ Symbolizm był do pewnego stopnia reakcją skierowaną przeciw naturalizmowi i chłodnemu parnasizmowi. Głoszono wyższość poznania intuicyjnego nad poznaniem empirycznym. ${ }^{5}$ Stosunek symbolizmu do spuścizny romantycznej był różny - inny w Europie, w tym Polsce, inny w Rosji. Stanisław Wyspiański w Nocy listopadowej i Wyzwoleniu problem romantycznego zrywu narodowowyzwoleńczego (np. postaci gen. Józefa Chłopickiego i Prometeusza) przedstawił w świetle groteski. Podobnie postąpił André Gide w Prometeuszu źle spętanym. Z kolei, Iwanow w tragedii-misterium Prometeusz w ogniu, młocie tytana dostrzegł wartości związane z heroiką rewolucyjną. Nawiązał spekulatywnie do mitu o Prometeuszu, który był tak popularny w romantyzmie. ${ }^{6}$ U Iwanowa, Briusowa

1 GORCZYCA, Wojciech: Briusow * Iwanow * Gumilow. Prawdy o micie, symbolu $i$ historii. Bielsko-Biała: Wydawnictwo Akademii Techniczno-Humanistycznej, 2008, s. 57-67, 109-117; GORCZYCA, Wojciech: Wschodni utopizm Wtodzimierza Sotowiowa i symbolistów rosyjskich. W: Problemy utopii i antyutopii w literaturach słowiańskich i historii Słowian. Red. W. Gorczyca - I. Pospíšil. Bielsko-Biała: Wydawnictwo Naukowe Akademii Techniczno-Humanistyczne, 2014, s. 177-180.

2 STEFANIAK, Łukasz: Utopizm. Źródta myślowe $i$ konsekwencje cywilizacyjne. Lublin: Wydawnictwo KUL, 2011, s. 143.

3 DĄBROWSKI, Mieczysław: Modernizm, awangarda, postmodernizm - próba catości. Sborník prací filozofické fakulty brněnské univerzity, X 8, 2005, s. 19-30.

4 BUSZKO, Józef - SMOLEŃ, Mieczysław: Literatura 1850-1914. W: Wielka historia świata, t. 10. Świat od Wiosny Ludów do I wojny światowej. Kraków: Fogra; Warszawa: Świat Książki, 2006, s. 465-467.

5 BARAŃSKI, Zbigniew: Symbolizm. W: BARAŃSKI, Zbigniew - SEMCZUK, Antoni: Literatura rosyjska w zarysie. T. II. Warszawa: PWN, 1975, s. 669.

6 GORCZYCA, Wojciech: Op. cit., 2008, s. 71-93. 
i Błoka po 1905 roku dały mocno o sobie znać idee Fryderyka Nietzschego (z „wolą mocy” i koncepcja „Nadczłowieka”), traktowane przez nich instrumentalnie oraz program Włodzimierza Sołowiowa (w tym wiersz, Panmongolizm - Панмонголизм, 1905).

Związek sztuki z socjalizmami modernistycznymi i awangardą nigdy Gippius jako poetki specjalnie nie interesował. Jej kontakty z eserami (w tym z Borysem Sawinkowem) w latach 1906-1921, należy kojarzyć przede wszystkim z jej działalnością, dotyczacą przemian cywilizacyjnych w Rosji po 1905 i 1917 roku, tj. odrzuceniem caryzmu i komunizmu oraz próbą uaktywnienia utopii związanej z Trzecią Rosją ${ }^{7}$. Zainteresowanie utopią polityczną i religijną, a później emigracja do Francji, tak sadzę, oddaliły Gippius od ewentualnych możliwości transformacji pozycji autonomicznej i sztuki wysokiej w kierunku poezji „empirycznej”. Czy w ogóle byłaby do tego zdolna?

Jako starszy symbolista (obok Konstantego Balmonta i Fiodora Sołoguba) autorka Luster (Зеркала, 1936) nigdy nie wykorzystywała symbolu instrumentalnie, tak jak np. Briusow. Uznawała sztukę za wartość autentyczną i autonomiczną. Wyróżniało ją zainteresowanie psychiką ludzką, wyodrębniona i personifikowaną jako postać, przedmiot penetracji poprzez „zejście w głąb” - pejzaż wewnętrzny jako jedna z odmian grupy odpowiedników introspekcji psychologicznej. ${ }^{8}$ Twierdziła: „Poeta pragnie tylko tego, czego nie ma na świecie." Jednocześnie podmiot liryczny Gippius wyróżnia motyw ucieczki od świata rzeczywistego, życie w świecie izolowanym. Poetka niewątpliwie była zainteresowana tezami Akima Wołyńskiego, który dowodził, że symbolizm jest sztuką religijną. ${ }^{10}$

O wiele lat młodszą od Gippius Cwietajewą różni m.in. to, iż nigdy nie należała do ugrupowania poetyckiego. Swój indywidualny program poetycki opracowała samodzielnie. Charakteryzował ją egocentryczny i antropocentryczny sposób postrzegania świata. Jej poetyckim credo było ustalenie: „Мое дело измена”. W procesie twórczym starała się nadawać „tej samej rzeczy” inny sens, określając jej zmienność znaczeniową w wymiarze metafory in absentia. ${ }^{11}$ Koresponduje to z określonymi charakterystykami postmodernizmu, o których pisze Bolesław Dąbrowski: „Żaden sens [...] nie jest dany raz na zawsze i w sposób oczywisty; też bywa zmienny, jest zadaniem do odkrycia, doktadniej nawet: do ustanowienia". ${ }^{12}$ Ma to oczywisty związek z dokonaniami Cwietajewej też jako poetki-feministki.

Przywołane w tytule artykułu symbole „znaczące” - ‘okno’ i ‘lustro’ u dwóch rosyjskich poetek skłaniają do udzielenia odpowiedzi na pytanie, jakie było odniesienie poetek do problemu nowości i oryginalności zarówno w warstwie semantycznej, jak i warstwie formalnej, tj. sposobie metaforycznego konstruowania sceny poetyckiej. Aby uchwycić

7 Piszę o tym szerzej w artykule Zinaida Gippius, symboliści, eserzy i Józef Pitsudski w czasopiśmie Slavica litteraria 21, 2018, č. 1, s. 15-21.

8 KWIATKOWSKA-PODRAZA, Maria: Symbolizm i symbolika w poezji Mtodej Polski. Kraków: Universitas, 2001, s. 190-191.

9 LOTMAN, Jurij - MINC, Zara: Simvolizm. B: Russkaâ literatura XX veka: školy, napravlenija, metody tvorčeskoj raboty. Red. S. Timina. Sankt-Peterburg: Logos; Moskva: Vysšaja škola, 2002, s. 21.

10 BARAŃSKI, Zbigniew: Op. cit., s. 669.

11 GORCZYCA, Wojciech: Mariny Cwietajewej myśli o Innym. Bielsko-Biała: Wydawnictwo Akademii Techniczno-Humanistycznej, 2004, s. 7, 28.

12 DĄBROWSKI, Mieczysław: Op. cit., s. 20-30. 
różnicę między sposobem ich konceptualizacji świata przedstawionego, warto jeszcze przywołać kilka danych na temat założeń postmodernizmu, przede wszystkim po to, aby cofając się wstecz, tj. do czasu powstania analizowanych w tym artykule wierszy Cwietajewej (powstałych w 1916 i 1919 roku), spróbować ustalić, na ile była im bliska.

Jak pisze Erazm Kuźma, postmodernizm określa się jako antyplatonizm, antykartezjanizm, antykantyzm, antyheglizm. Ta odrzucona tradycja cechowała się dążeniem do Jedności, do Całości, która jest Prawdą. Antytradycja postmodernizmu w układzie wertykalnym nacechowana była wektorem skierowanym ku górze, postmodernizm odwrotnie - skierowanym ku dołowi. Te opozycje można mnożyć: w górze światło, w dole ciemność, po jednej stronie duch, po przeciwnej ciało - po jednej stronie idea tożsamości i sprzeczności kumulująca się w Heglowskiej dialektyce, po drugiej idea powtórzenia i różnicy. ${ }^{13}$ Jak wiadomo, bunt przeciw tej tradycji podniósł Fryderyk Nietzsche, który stwierdzal, że słabi dążą do tożsamości, jedności, stałości; mocni - przeciwnie; do zmienności, różności, wielości. ${ }^{14}$

Skonfrontujmy zatem wiersze Gippius i Cwietajewej o 'oknie', zwracając szczególną uwagę na specyfikę układów wertykalnych przestrzeni, w tym na problem stałości i zmienności. Pożyteczną „podpowiedzią” w tym zakresie może być krótka analiza obrazu Caspara Davida Friedricha Kobieta w oknie.

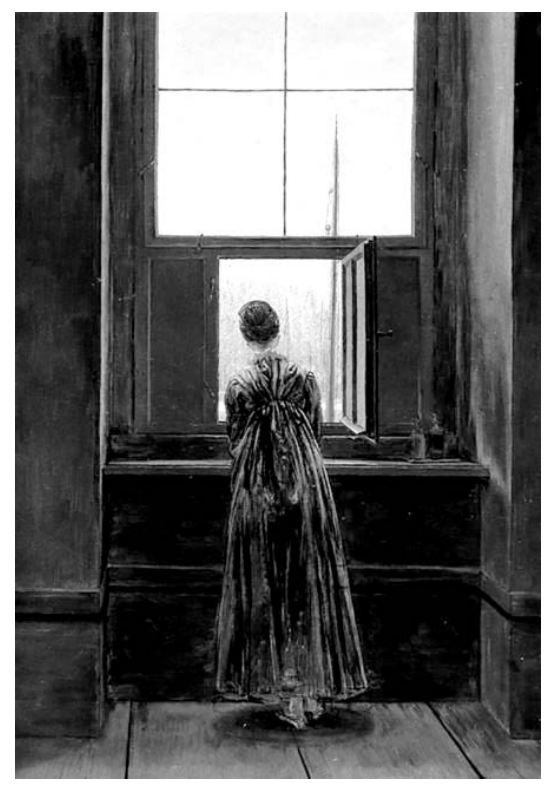

Caspar David Friedrich: Kobieta w oknie

Obraz ten należałoby analizować wespół z obrazem Georga Friedricha Kerstinga Caspar David Friedrich w swojej pracowni, na którym, dolna część okna jest zamknięta.

13 KUŹMA, Erazm: Postmodernistyczna idea powtórzenia i różnicy przeciw modernistycznej idei tożsamości $i$ sprzeczności. W: Ponowoczesność a tożsamość. Red. B. Tokarz - S. Piskora. Katowice: Stowarzyszenie Pisarzy Polskich, 1997, s. 62. 
Egzaltacja własnego ja i żywiołu lirycznego jako powszechnego elementu romantycznego jest tutaj ewidentna. Obraz Kerstinga duże górne okno z cienką ramą pozostawia artyście. W tym sensie okno reprezentuje indywidualizm, subiektywność, wolność twórczej fantazji genialnych jednostek - jest Całością.

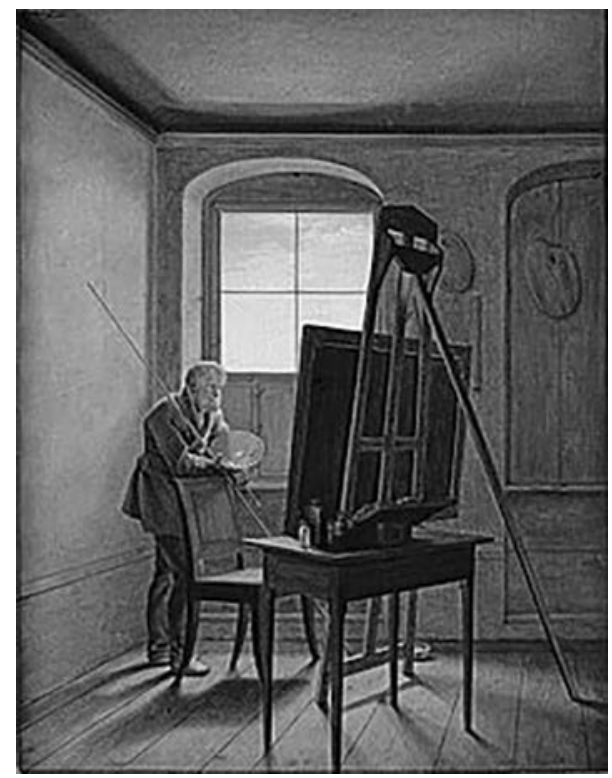

Georg Friedrich Kersting: Caspar David Friedrich w swojej pracowni

Górna część okna na obrazie Caspara dominuje i to ona tworzy całość, nawet wtedy, kiedy dolna część jest otwarta. Eksponowanie przestrzeni wertykalnej jest tutaj ewidentne - to element stały obrazu. Górna część z zaznaczoną cienką ramą okienną sugeruje jednocześnie, że kontakt człowieka (kobiety) z przyrodą następuje przede wszystkim przez dolną część okna, co z twórczą fantazją i kultem silnych przeżyć związane nie jest. Wskazuje wszakże na element istotny - przybliża „powszednią” czynność kobiety, to, co realne, z mistyką nie związane.

Taka koncepcja prezentuje niewątpliwie romantyczny kult przyrody Caspara - poety i malarza. Jednocześnie człowiek pozostający we wnętrzu i wyglądający przez okno to motyw mający dla Caspara (dla romantyzmu niemieckiego w ogóle) znaczenie psychologiczno-symboliczne. ${ }^{15}$

Jak w tej sytuacji mają się efekty percepcji 'okna' dwóch poetek rosyjskich do kulturowych wartości tej kategorii oraz do antytradycji modernizmu i postmodernizmu? Okno jako rodzaj otworu, wyraża pojęcie wnikania, możliwości i dalekiej perspektywy; z racji czworokątnego kształtu jego sens konotuje przyziemność i racjonalność. Jest również symbolem świadomości, zwłaszcza gdy pojawia się w górnej części wieży, analogicznej

15 RZEPIŃSKA, Maria: Siedem wieków malarstwa europejskiego. Wrocław: Zakład Narodowy im. Ossolińskich, 1986, s. 382. 
wszak z postacią ludzką. Okno wielodzielne niesie sensy poboczne mogące nakładać się na główny; są one pochodnymi liczby otworów oraz związków zachodzących między symboliką tej liczby a ogólnym sensem okna. ${ }^{16}$

Motyw 'okna' zainteresował Gippius tuż po ukazaniu się w 1892 roku pierwszego manifestu symbolizmu rosyjskiego autorstwa Dymitra Mereżkowskiego O przyczynach upadku i o nowych kierunkach we wspótczesnej literaturze rosyjskiej. ${ }^{17}$ Swoim rozważaniom poetyckim nadała formę takiego gatunku literackiego, jakim jest pieśń (Pieśn - Песнъ, 1893). Oznacza to, że występuje w tekście Gippius tendencja do regularnego układu rytmicznego. Występują w nim liczne paralelizmy leksykalne i powtórzenia, częste posługiwanie się refrenem, skłonność do paralelizmu składniowego i prostej organizacji syntaktycznej. ${ }^{18}$

Окно мое въсоко над землею,

Въцско над землею.

Я вижу только небо с вечернею зарею,

С вечернею зарею.

И небо кажется пустым и бледным,

Таким пустьм и бледнъм...

Оно не сжалится над сердием бедным,

Над моим сердием бедным.

Dominuje w wierszu układ wertykalny dół-góra, co wiązać należy z pojęciem wnikania, możliwości i dalekiej perspektywy. Taki układ symbolizuje też świadomość. Okno jest tutaj łącznikiem między lirycznym ja a sferą transcendencji, skłania ku próbie przekroczenia granic ludzkiego poznania, zrozumienia wieczności, jakkolwiek jest to trudne do osiagnięcia („Стремлюсь к тому, чего не знаю”). Gippius chodzi bardziej о tо „чего нет на свете", о wykreowanie odpowiedniego nastroju, w czym zbliża się do Afanasija Feta, aniżeli pokazanie czynności penetracyjnych związanych z „introspekcja psychologiczną". ${ }^{19}$ Pojawiają się w wierszu smutek, tęsknota i płacz. Niebo z wieczorną zorzą, wydaje się puste i blade. Nie nastraja optymistycznie.

Przyjęcie formy pieśni było zapewne intencją poetki zmierzającą do zniwelowania dystansu między wykreowanym stanem „wnętrza” lirycznego ja a odbiorcą. Tak czy inaczej prostota formy niekoniecznie musiała odpowiadać „wygórowanym ambicjom” lirycznego ja, tj. temu, „czego nie ma na świecie” („Мне нужно то, чего нет на свете”). Podmiot ów jest „słaby”, jakkolwiek jego status określa chęć utożsamienia się z „niebem wysokim”. Pojawiające się „sprzeczności” oscylujące między 'śmiercią’ i obietnicą “cudu' przemawiają za tym, iż wiersz Gippius należy łączyć z antytradycją postmodernizmu. Potwierdza to

16 CIRLOT, Juan Eduardo: Stownik symboli. Przeł. I. Kania. Kraków: Społeczny Instytut Wydawniczy Znak, 2006, s. 284.

17 BARAŃSKI, Zbigniew: Op. cit., s. 668.

18 KOŁACZKOWSKA, Anna: Pieśn. W: Słownik rodzajów i gatunków literackich. Red. G. Gazda - Sł. Tynecka-Makowska. Kraków: Universitas, 2006, s. 532.

19 KWIATKOWSKA-PODRAZA, Maria: Op. cit., s. 191. 
ustalenia Lyotarda, który wskazuje na dwie tonacje relacji między tym, co pojmowalne a tym, co przedstawiane, dwie tonacje doświadczenia, które jest wyzwaniem dla możliwości wyobraźni. Gdy artysta skłania się ku nostalgii za obecnością, akcentując bezsilność władzy przedstawienia, przyjmuje postawę bliższą modernistom. ${ }^{20}$

Kolejny wiersz Gippius Żótte okno, jeśli chodzi o proces nadawania sensów „górze” i „dołowi” daje się odczytać jako „profanacja” nieba, której dokonała ziemia (albo obecność „piekła na ziemi i w niebie”). Funkcja przyrody została zmieniona na metaforyczną. Przede wszystkim uderza zmiana ‘stałych' wartości przypisanych „górze” i „dołowi”. Oto niebo staje się niebem dzikim i podziemnym („Взгляни, как небо дико, Подземно и светло").

Powstaje w ten sposób pejzaż semantyczny jako pożar, w którego nazwie oznaczającej zjawiska psychiczne (zaskoczenie, przerażenie, przeczucie śmierci) każdorazowo towarzyszy nazwa elementu pejzażu. ${ }^{21}$ Jego wartość-kategorię określa to, co „podziemne” z barbarzyństwem związane („Ручей по дну оврага как черное вино”).

Pejzaż o charakterze Armargedonu, w którym skumulowały się wartości 'ujemne', powstaje jako łańcuch kojarzeń - jedno ogniwo wywołuje następne. Niebo dzikie i podziemne wywołuje płynący po dnie wąwozu czarny jak wino strumień. Efekty spalania z ich kolorem ‘żółtym' oznaczającym śmierć, prowadzą liryczne ja do spostrzeżenia tego, co najgorsze. Stąd wszechobecne przeklęte okna i wyblakła ziemia.

\section{И всюду эти стекла \\ Проклятого окна. \\ Земля моя поблекла, \\ Земля опалена}

Okno u Gippius funkcjonuje zgodnie ze znaczeniem archetypowym - wyraża pojęcie wnikania, możliwości i dalekiej perspektywy. Obserwowane poetycko efekty rewolucji październikowej prowadzą do nieba, które zostało zamienione na piekło. Liryczne ja jako obserwator konotuje okrutna przyziemność i racjonalność „dzieła” Lenina oraz akcentuje wzniosłość swego przerażenia. Mimo wprowadzenia elementów myślenia asocjacyjnego polegającego m.in. na wykorzystaniu metafory interakcyjnej („Бессмысленно-кровавъ тела апрельских рощ”.) oraz oksymoronu, zauważalna w wierszu estetyka wzniosłości posiada funkcję melancholijną. ${ }^{22}$ Potwierdza to cytowana wyżej ostatnia strofa wiersza.

Występujące w niej 'szyby' (стекла), skłaniają do odczytania sensów tej kategorii w wierszu Gippius z 1904 roku pod tytułem Szyba (Стекло). Sytuację liryczną w Szybie możemy określić jako intymną, stymulowaną pojęciem „przeszkody” nie do przejścia. Ową przeszkodą jest „ciemna szyba”: „Но в жизни нашей, не случайно,/ Развединяя нас, легло/ Меж нами темное стекло”. Dochodzi do tego jeszcze jeden 'wrogi' atrybut, mianowicie „szklany chłód” („И страшен мне стекляннй холод”). Liryczne ja usiłuje przekroczyć

20 POPIEL, Magdalena: $O$ nowa estetyke. W: Kulturowa teoria literatury. Red. M. P. Markowski - R. Nycz. Kraków: Universitas, 2006, s. 343.

21 KWIATKOWSKA-PODRAZA, Maria: Op. cit., s. 193.

22 POPIEL, Magdalena: Op. cit., s. 243. 
granicę między tym, co „wewnętrzne”, a tym, co „zewnętrzne”23 - między światem rzeczywistości realnej, którą określa „ciemna szyba” a światem poetyckiej wyobraźni - fantastyki („,...] там, где все необычайно”).

Generalnie symbolika 'mgły' wiąże się z przejściem, ewolucją i interwencją sił nadprzyrodzonych. Mgła może oznaczać też fazę poprzedzającą objawienie. ${ }^{24}$ Gippius nie nadaje mgle żadnego z tych znaczeń - wręcz przeciwnie, mgła jest zasłoną, która dodatkowo wzmacnia 'chłód szkła'. W walce o złamanie „przeszkody” ucieka się do apostrofy: „Любовъ, Любовъ! О дай мне молот”. Symbolika młota zyskuje u Gippius niszcząco-twórczy wymiar. Poetka pamięta zapewne, że młot rzadko jest tylko symbolem brutalnej siły. ${ }^{25}$ W mitologii skandynawskiej powoływano się na młot Tora, zawierając kontrakty i małżeństwa. 'Młot' jako narzędzie w ręku podmiotu lirycznego zyskuje w wierszu konotacje boskie, czego konsekwencja jest przywołanie Istoty Boskiej w ostatniej strofie i konstataсја: „Услышит Бог. .../Он даст нам сил разбить стекдо”.

Niewątpliwie wiersz Gippius przywraca wartość sprzeczności doznań - bólu, niemożności i nadziei. Poetka mówi o oporze, który stara się przełamać. Jej estetyka wzniosłości i w tym przypadku posiada wersję melancholijną, która nie zlikwiduje „szyb przeklętego okna”.

Melancholii w kreowaniu motywu ‘okna’ nie znajdziemy u Mariny Cwietajewej. Wieczna buntownica w wierszu o incipicie „Высоко мое оконие...” (1919) występuje z „pejzażem wewnętrznym” konstruowanym za pomocą metody wolnych skojarzeń i myślenia uskokowego, co zbliża ją do słynnego „strumienia świadomości”. Mechanizmem generującym wypowiedź poetycką Cwietajewej jest jej percepcja, wyobrażenie oraz fizyczny wymiar doświadczenia. Przełamanie oporu jest w wierszu szybkie, prawie natychmiastowe. Okazuje się, iż „dosięgnięcie” “wysokiego' jest możliwe, ale nie w sferze estetyki wzniosłości, stymulowanej melancholią.

\section{Высоко мое оконие! \\ Не достанешь перстеньком! \\ На стене чердачной солние \\ От окна легло крестом. \\ Тонкий крест оконной рамъ. \\ Мир. - На вечны времена. \\ И мерешится мне: в самом \\ Небе я погребена!}

W przypadku wiersza Cwietajewej okno-słońce to krzyż, a krzyż to świat. Pojęcia te unaoczniają się dzięki ramie okiennej (część) - dzięki temu, że istnieje ona w działaniu i doświadczeniu poetki oraz posiada te właściwości, które im nadaje w swych czynno-

23 KWIATKOWSKA-PODRAZA, Maria: Op. cit., s. 211.

24 TRESIDDER, Jack: Stownik symboli. Przeł. B. Stokłosa. Warszawa: RM, 2001, s. 129.

25 Ibidem, s. 132. 
ściach i doznaniach. ${ }^{26}$ Mapowanie wyznacza tutaj bogatą strukturę zależności pomiędzy poszczególnymi elementami konceptualizacji - jest koherencyjne. „Część” (rama okienna) zatem stanowi o poziomie bazowym kategorii 'okno'. Zastępuje „całość.

Jak widać, zjawisko odbicia u Cwietajewej to nie tylko fizyczny problem refrakcji promieni świetlnych. ${ }^{27}$ Odbitą „rzecz” w tym wierszu tworzy krzyż - ściślej - cień ramy okiennej w formie krzyża. Cwietajewa nie używa pojęcia 'cień', który rzeczywiście tworzy kształt krzyża na rozgrzanej słońcem ścianie strychu. Rzeczy powszednie: ściana strychu, rama okienna i ukochany 'przedmiot' poetki, jakim jest słońce, tworzą nową kategorię 'okna', które nie jest „oknem na świat” (jak u Gippius), lecz oknem ze świata do wewnątrz i wskazują na pozytywną interakcję między centrum i peryferią. ${ }^{28}$

Metafizyka Gippius jest kojarzona tradycyjnie z Bogiem. U Cwietajewej w wierszu o 'oknie' metafizyką staje się sytuacja, zdarzenie. Wysokie okno (takie jak u Caspara) zostaje przy pomocy poetycko zaaranżowanej sytuacji poddane oddziaływaniu słońca w interakcji ze ścianą strychu. Rama okienna, ściana i strych nie są słownictwem wyrafinowanym, raczej codziennym i, jak sądzę, swoistą transformacją koncepcji dwóch okien niemieckiego artysty, transformacją, która w wyobraźni twórczej Mariny Cwietajewej tworzy amalgamat. ${ }^{29}$

Wiersz przekonuje, że Cwietajewa skupia swoją uwagę na ciągłych próbach „pomnażania istnienia" i czerpie radość z wynalezienia nowych reguł. Jest to nastawienie typowe dla postmodernisty. ${ }^{30}$ Wektor doświadczenia Cwietajewej jest w wierszu skierowany ku dołowi, a bohaterem w ujęciu fizykalnym okazuje się cień krzyża. Implikuje to niewątpliwie zmianę w postrzeganiu 'okna', zmianę przypisującą duże znaczenie „części”. W ten sposób widocznej na obrazie Caspara ramie okiennej, nadała Cwietajewa wartość „przyziemną", która okazała się tak samo ważna jak niewielkie otwarte okno, przez które ogląda świat przyrody kobieta. Inny był jednak gender kobiety wtedy, gdy tworzył swój obraz Caspar - o inny gender kobiety walczyła Marina Cwietajewa.

Pejzaż wewnętrzny Zinaidy Gippius w analizowanych wierszach o 'oknie' był budowany na rozdźwiękach między emocjonalnym a poznawczym odniesieniem do kreowanych wizji przy jednoczesnej obserwacji paradygmatów mitu (też magii) i religii, na rozdźwiękach między wyobraźnią twórczą funkcjonującą w przestrzeni wirtualnej a kulturową pamięcią i doświadczeniem historycznym - w tym politycznym, jak w przypadku wiersza Żótte okno. ${ }^{31}$ Rozdźwięki owe wiążą się z wektorem doświadczenia, który był budowany

26 GORCZYCA, Wojciech: Op. cit., 2004, s. 19.

27 LORENC, Iwona: Świadomość i obraz. Studia z filozofii przedstawienia. Warszawa: Scholar, 2001, s. 35; GORCZYCA, Wojciech: Op. cit., 2004, s. 18.

28 KOMENDZIŃSKI, Tomasz: Znak i jego ciagtość. Semiotyka Ch.S. Peirce’a. Między percepcja a recepcja. Toruń, UMK, 1996, s. 62-65.

29 LIBURA, Agnieszka: Amalgamaty kognitywne. Powstanie i rozwój koncepcji. W: Amalgamaty kognitywne w sztuce. Red. Taże. Kraków: Universitas, 2007, s. 12-16.

30 POPIEL, Magdalena: Op. cit., s. 343.

31 ŚLÓSARSKA, Joanna: Nazgul i Chrystus. Dystopijne lustra komunikacyjne w prozie Jacka Dukaja (na podstawie opowiadan Z kraju niewiernych). W: Problemy utopii i antyutopii w literaturach słowiańskich i historii Słowian. Red. W. Gorczyca - I. Pospísili. Bielsko-Biała: Wydawnictwo Akademii Techniczno-Humanistycznej, 2014, s. 90. 
ku górze, na bazie estetyki wzniosłości z domieszką tonacji melancholijnej (Pieśn i Szyba). Wektor wzniosłości charakterystyczny dla modernizmu w wierszu Żótte okno został ujęty w sposób demonologiczny, tj. „górze-niebu” w wyniku wstrząsu psychicznego wywołanego nowym doświadczeniem politycznym przypisała Gippius właściwości „dołu-ziemi”. W ten sposób 'okna' zostały przeklęte.

W napisanym w 1936 roku wierszu pt. Zwierciadta (Зеркала) poetka utożsamia „górę”, z „dołem”, wprowadzając rozwiązanie polegające na tym, że lustro umieszczone w górze odbija 'trawę', natomiast umieszczone na dole, 'chmurę. Podstawę sądów stanowi twierdzenie o fałszywości odbicia „świata przyrody”. Taki punkt widzenia koresponduje, według mnie, z tradycją hinduistyczną i buddyjską, w której lustro symbolizuje oświecenie duchowe, przynoszące świadomość, że świat zjawisk (natury) jest złudzeniem, odbiciem prawdziwej rzeczywistości, a nie nią samą. ${ }^{32}$

Везде зеркала сверкали.
Внизу, на поляне, с краю,
Вверху, на березе, на ели.
$[\ldots]$
Но каждое было лукаво...

Kojarzy się to nieodparcie ze przekonaniem, że prawdziwe poznawczo są tylko idee, będące w świadomości odpowiednikiem przedmiotów. ${ }^{33}$ Ekwiwalent znaczący (polana, brzoza, jodła) przechodzi w wierszu w wartość autonomiczną, a symbol zbliżony do alegorii zmienia się w utwór należący do poezji „czystej”. ${ }^{34}$ Lustra Gippius funkcjonuja w przestrzeni, która umożliwia z jednej strony ogląd, zdawałoby się, wielostronny (внизу, с краю, вверху), z drugiej, jak podkreśliłem, lustra „kłamią”, pokazując ‘trawę’ na górze, a 'chmurę' na dole. Tym razem nie ma tu mowy o tradycji myśli chrześcijańskiej (też islamskiej) o tym, że serce człowieka przyrównuje się do lustra, które odbija Boga. ${ }^{35}$

Precyzując wnioski na temat różnicy miedzy Gippius i Cwietajewą w kreowaniu motywu lustra, zwrócę najpierw uwagę na naturalne i transcendentalne odbicie w lustrze. ${ }^{36}$ W ujęciu naturalnym, tym co rozstrzyga, że odbicie w lustrze odbieramy jako obraz nas samych, jest wiara postrzeżeniowa. To dzięki niej jesteśmy przekonani, że treści naszej świadomości i postrzeżeń są adekwatne do świata rzeczywistego, który bez wątpienia istnieje. Jeśli natomiast chodzi o ujęcie transcendentalne, koncentrujemy się na treściach odbitych tak, jak byśmy byli wewnątrz zwierciadła. Nastawienie naturalne nasuwa porównanie do sytuacji podmiotu empirycznego, który widzi w lustrze swoje fikcyjne odbicie; ja empiryczne jest realnością przeciwstawioną fikcji obrazu. W ujęciu transcendentalnym

32 TRESIDDER, Jack: Op. cit., s. 116-117.

33 STEFANIAK, Łukasz: Op. cit., s. 148.

34 KWIATKOWSKA-PODRAZA, Maria: Op. cit., s. 214.

35 TRESIDDER, Jack: Op. cit., s. 117.

36 LORENC, Iwona: Op. cit., s. 85. 
natomiast podmiot rozpatruje treści swej własnej świadomości i spostrzeżeń z „wyłączeniem" świadomości siebie jako ja empirycznego. ${ }^{37}$

Autonomiczny sposób uprawiania poezji, „czysta sztuka”, której Gippius była wierna do końca swych dni, skłonił ją do tego, aby wiązać lustro z myślą, że jest ono organem autokontemplacji. ${ }^{38} \mathrm{~W}$ tym sensie Gippius wykreowała poniekąd lustro na miarę Narcyza, „dostrzegając w nim” przede wszystkim własne konstrukcje. Sukcesem poetki jest niewątpliwie to, że spostrzega fałszywe odbicia luster, a także to, iż zauważa multiplikację owych „zawłaszczających” świat odbić.

W mitach lustro występuje jako brama, przez którą wyswobodzona od ciała dusza może „przejść” na druga stronę. Lustro może być także specyficznym symbolem morza płomieni (życie jako choroba). Wydaje się, iż u Gippius ma miejsce owo ambiwalentne znaczenie lustra. W związku z tym ma kłopoty z przejściem przez „bramę”, ma kłopoty z rozbiciem „szyby”, prześladują ją „szyby przeklęte”. Bez tych kłopotów jednak nie powstałaby jej poezja, w tym Lustra („И в каждом - зари розовенъе/ Сливалось с зеленостью травной).

Problemów z lustrem, które „kłamie”, nie miała Marina Cwietajewa. Często liryczne ja Cwietajewej, jakkolwiek „przygniecione” posępnością i smutkiem, szuka, określając wprost swój stan wewnętrzny, wyjścia z sytuacji. Bywa, że stosuje rozwiązania drastyczne - też wtedy, gdy skupia swą uwage na próbach „pomnażania istnienia” i czerpie radość $\mathrm{z}$ wynalezienia nowych regut. ${ }^{39}$ Nową reguła w przypadku wiersza o incipicie Разлетелосъ в серебряные... (1916) jest „uderzenie” w lustro. Nieosiągalny dla Gippius 'młot' znajduje Cwietajewa jako 24-letnia poetka, wydawałoby się, bez problemów.

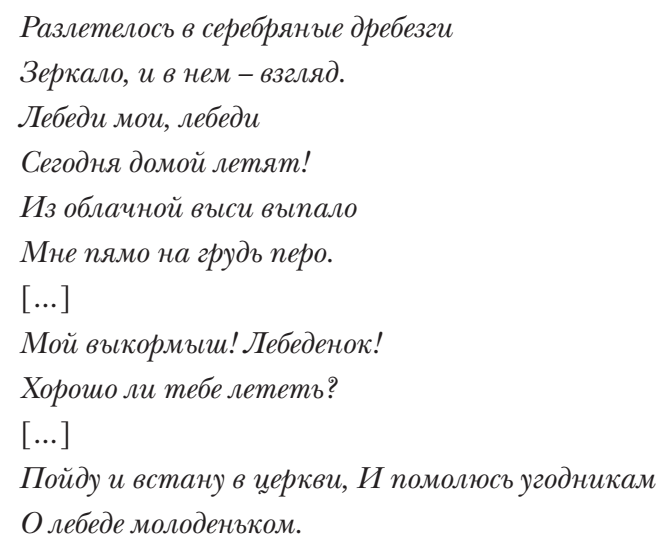

Istotna jest w drugiej strofie pauza. Podkreśla istotność rozpadu „spojrzenia”, tj. punktu widzenia, oceny sztuki, własnych dokonań. Przejawia się w tym niewątpliwie negacja

37 Ibidem, s. 86.

38 CIRLOT, Juan Eduardo: Op. cit., s. 237.

39 POPIEL, Magdalena: Op. cit., s. 343. 
założeń tak zwanego wysokiego modernizmu ${ }^{40}$ w tym autonomiczności. „Uderzenie” implikuje inne niż w modernizmie rozumienie relacji zawierania się "góry” z „dołem”. Mamy w wierszu do czynienia z aktywnym układem przestrzennym: „góra-dół”; „dól-góra”; "góra-dól”, który implikuje obecność dwóch istotnych w wierszu elementów: 'pióra' i 'piersi' („Из облачной выси выпало/ Мне прямо на грудь перо”). Dusza „wewnętrznie niespójna” doprowadza do „uderzenia”, które rodzi różnicę między melancholijno-nostalgicznym marzeniem Gippius o wyzwoleniu się spod władzy czarnego szkła, a efektem likwidacji „spojrzenia”. Zauważmy, iż efekt ten rodzi nowy rodzaj kobiecej delikatności, którą egzemplifikuje 'pióro'. U Cwietajewej łączy się ono z lekkością tworzenia. W wierszu występuje także jako reprezentacja modlitwy i wiary. ${ }^{41}$ 'Pierś', z kolei, reprezentuje bezpieczeństwo, ochronę i lagodność.

Białe pióro przypadkowo zgubione przez łabędzia nieprzypadkowo kreuje stan cichej refleksji. Wiersz Cwietajewej jest swoistym dialogiem poznania z instynktem. ${ }^{42}$ Najpierw obserwujemy aktywność pierwiastka męskiego („uderzenie o”), następnie kobiecą delikatność, wysoko wzniesiony świat i, co decyduje o novum, w porównaniu z Gippius, wprowadzenie takich kategorii, jak matka, krewni, cerkiew, święci, którym Cwietajewa nie nadaje znaczenia wzniosłego.

Symbol znaczący 'labędź', tak popularny w romantyzmie i symbolizmie, zyskuje w wierszu Cwietajewej kompletnie inne konotacje. Poetka odrzuca mistyczno-tajemniczy walor łabędzia. Nie jest to ptak, który tak jak w Fedonie Platona śpiewa w obliczu śmierci, ponieważ przeczuwa nieśmiertelność. Wreszcie, nie jest to ptak królewski uważany wprost za symbol poety. ${ }^{43}$ Inność konceptualizacji 'lustra' u Cwietajewej w porównaniu z Gippius polega przede wszystkim na wyzwoleniu się „z okowów” sztuki czystej i odrzuceniu pozycji poety-demiurga. Eksponowanie wektora skierowanego ku dołowi, widoczna idea powtórzenia i różnicy (zamiast łabędzia labędziątko; zamiast Boga Wszechmogącego cerkiew i święci oraz modlitwa za labędziątko), wreszcie aktywność pierwiastka męskiego, co łączy Cwietajewą z „pierwszą falą” feminizmu, której sztandarowym hasłem była równośćc ${ }^{44}$ decyduje o różnicy poezji wiecznej buntownicy w porównaniu z osiagnnięciami Zinaidy Gippius.

Dodatkowo różnicę tworzy fakt, że Cwietajewą cechuje myślenie uskokowe, co wiąże się z funkcjonowaniem metafory in absentia, w której trzeba przeformułować odczytanie pod wplywem informacji napływających $\mathrm{z}$ dalszego kontekstu ${ }^{45}$. Ten rodzaj poetyckiego myślenia jest Gippius obcy, jakkolwiek trudno jej odmówić rozwiązań kreatywnych (szczególnie w wierszu Żótte okno). W głównej mierze posługuje się metaforą-porównaniem oraz epitetem.

40 BURZYŃSKA, Anna: Poststrukturalizm. W: Teorie literatury XX wieku. Red. Taże i M. P. Markowski. Kraków: Universitas, 2007, s. 338.

41 TRESIDDER, Jack: Op. cit., s. 164-165.

42 GORCZYCA, Wojciech: Op. cit., 2004, s. 33.

43 KWIATKOWSKA-PODRAZA, Maria: Op. cit., s. 137.

44 KUŹMA, Erazm: Op. cit., s. 62; BURZYŃSKA, Anna: Feminizm. W: Teorie literatury XX wieku. Red. Taże i M. P. Markowski. Kraków: Universitas, 2007, s. 393. 
Jest więc Cwietajewa, w myśl twierdzenia Nietzschego, poetką mocną, dążącą do zmienności i różności. Między innymi dlatego, że odrzuca ustalenie, iż rozbicie lustra przynosi nieszczęście, co wiąże się z wierzeniem jakoby lustrzane odbicie człowieka zawierało część jego sił witalnych lub bliźniaczą duszę. ${ }^{46}$

\section{Bibliografia}

BARAŃSKI, Zbigniew: Symbolizm. W: BARAŃSKI, Zbigniew - SEMCZUK, Antoni: Literatura rosyjska w zarysie. T. II. Warszawa: PWN, 1975, s. 668-694.

BURZYŃSKA, Anna: Poststrukturalizm. W: Teorie literatury XX wieku. Red. Taże i M. P. Markowski. Kraków: Społeczny Instytut Wydawniczy Znak, 2006, s. 305-358.

BURZYŃSKA, Anna: Feminizm. W: Teorie literatury XX wieku. Red. Taże i M. P. Markowski. Kraków: Społeczny Instytut Wydawniczy Znak, 2006, s. 389-438.

BUSZKO, Józef - SMOLEŃ, Mieczysław: Literatura 1850 -1914. W: Wielka historia świata, t. 10. Świat od Wiosny Ludów do I wojny światowej. Kraków: Fogra; Warszawa: Świat Książki, 2006, s. $457-490$.

CIRLOT, Juan Eduardo: Stownik symboli. Przeł. I. Kania. Kraków: Społeczny Instytut Wydawniczy Znak, 2006.

CVETAEVA, Marina. Sobranie sočinenij v semi tomach. T. 1. Moskva: Ellis Lak, 1994.

DĄBROWSKI, Mieczysław: Modernizm, awangarda, postmodernizm - próba catości. Sborník prací filozofické fakulty brněnské univerzity, X 8, 2005, s. 19-30.

DOBRZYŃSKA, Teresa: Mówiac przenośnie... Studia o metaforze. Warszawa: IBL PAN, 1994.

GORCZYCA, Wojciech: Mariny Cwietajewej myśli o Innym. Bielsko-Biała: Wydawnictwo Akademii Techniczno-Humanistycznej, 2004.

GORCZYCA, Wojciech: Briusow * Iwanow * Gumilow. Prawdy o micie, symbolu i historii. Bielsko-Biała: Wydawnictwo Akademii Techniczno-Humanistycznej, 2008.

GORCZYCA, Wojciech: Wschodni utopizm Wtodzimierza Sotowiowa i symbolistów rosyjskich. W: Problemy utopii i antyutopii w literaturach słowiańskich i historii Słowian. Red. W. Gorczyca I. Pospíšil. Bielsko-Biała: Wydawnictwo Akademii Techniczno-Humanistycznej, 2014, s. 167-182.

KOŁACZKOWSKA, Anna: Pieśń. W: Słownik rodzajów i gatunków literackich. Red. G. Gazda Sł. Tynecka-Makowska. Kraków: Universitas, 2006, s. 530-532.

KOMENDZIŃSKI, Tomasz: Znak i jego ciagtość. Semiotyka Ch. S. Peirce'a. Między percepcja a recepcja. Toruń: UMK, 1996.

KUŹMA, Erazm: Postmodernistyczna idea powtórzenia i różnicy przeciw modernistycznej idei tożsamości i sprzeczności. W: Ponowoczesność a tożsamość. Red. B. Tokarz - S. Piskora. Katowice: Stowarzyszenie Pisarzy Polskich, 1997, s. 62-73.

KWIATKOWSKA-PODRAZA, Maria: Symbolizm i symbolika w poezji Mtodej Polski. Kraków: Universitas, 2001.

LIBURA, Agnieszka: Amalgamaty kognitywne. Powstanie i rozwój koncepcji. W: Amalgamaty kognitywne w sztuce. Red. Taże. Kraków: Universitas, 2007, s. 11-68.

46 TRESIDDER, Jack: Op. cit., s. 117. 
LORENC, Iwona: Świadomość i obraz. Studia z filozofii przedstawienia. Warszawa: Scholar, 2001.

LOTMAN, Jurij - MINC, Zara: Simvolizm. B: Russkâ literatura XX veka: školy, napravlenija, metody tvorčeskoj raboty. Red. S. Timina. Sankt-Peterburg: Logos; Moskva: Vysšaja škola, 2002, s. $13-30$.

POPIEL, Magdalena: O nowa estetyke. W: Kulturowa teoria literatury. Red. M. P. Markowski R. Nycz. Kraków: Universitas, 2006, s. 335-366.

RZEPIŃSKA, Maria: Siedem wieków malarstwa europejskiego. Wrocław: Zakład Narodowy im. Ossolińskich, 1986.

STEFANIAK, Łukasz: Utopizm. Źródta myślowe i konsekwencje cywilizacyjne. Lublin: Wydawnictwo KUL, 2011.

ŚLÓSARSKA, Joanna: Nazgul i Chrystus. Dystopijne lustra komunikacyjne w prozie Jacka Dukaja (na podstawie opowiadań Z kraju niewiernych). W: Problemy utopii i antyutopii w literaturach słowiańskich i historii Słowian. Red. W. Gorczyca - I. Pospíšil. Bielsko-Biała: Wydawnictwo Akademii Techniczno-Humanistycznej, 2014, s. 89-106.

TRESIDDER, Jack: Stownik symboli. Przeł. B. Stokłosa. Warszawa: RM, 2001.

GIPPIUS, Zinaida: Želtoe okno. Желтое ожно. gippius.com/lib/poety

GIPPIUS, Zinaida: Pesnia. Песня. rupoet.ru/gippius/okno-moe-vysoko.aspx

GIPPIUS, Zinaida: Steklo. Стекло. poet4you.ru/classic/gippius/steklo.html

GIPPIUS, Zinaida: Zerkala. Зеркала. rupoet./Ru/gippius/a-vy-nikogda.aspx

Poradnik pisania. „Kobieta w oknie“, Caspar David Friedrich - opis obrazu. http://koloredaktorow.blogspot.com/2017/05/kobieta-w-oknie-caspar-david-friedrich.html

Wojciech Gorczyca, profesor emeritus

ul. Bratnia 35B, 43-354 Czaniec, Polsko

wgorczyca@ath.bielsko.pl

wojtekgorczyca42@gmail.com 